\title{
South Africa's foreign and migration policies missteps: fuels of xenophobic eruptions?
}

\author{
$S M M A D U E^{l}$
}

\begin{abstract}
South Africa plays a crucial role in the development of the African continent, especially in the South African Development Community. Hence, South Africa's foreign and migration policies shape the perceptions of both its citizens and those of neighbouring states. Since 1994, South Africa has continued to attract the highest number of migrants in the region. The widespread perceptions among South Africans that there are "floods" of illegal immigrants, stealing their jobs and depleting social and economic resources, is a course for concern. Undoubtedly, the South African society is under pressure to effectively respond to the sporadic eruptions of xenophobic attacks on African foreign nationals. This article argues that the missteps of South Africa's foreign and migration policies partially contribute towards fuelling xenophobic attacks on foreign nationals. The findings of this article suggest that South Africa is not as committed to rooting out xenophobia as it would have us believe.
\end{abstract}

Keywords: foreign policy, migration, multilateralism, xenophobia

\section{Introduction}

The context of migration to South Africa has changed exponentially since 1994. The democratic government has rapidly embraced entry into the global arena, pursuing neo-liberal economic policies aimed at encouraging the free movement of international trade and capital. An area of contradiction, however, is related to the free movement of people, particularly African unskilled economic migrants (often in the form of informal sector traders) and refugees (Handmaker \& Parsley, 2001: 41). There are widespread perceptions among South Africans that there are "floods" of illegal immigrants entering South Africa. These perceptions and other related myths, as well as the economic and social struggles of the South Africans often ignite sporadic xenophobic attacks of the foreigners. Palmary (2003) stresses that "... xenophobic attitudes indeed have translated into violent attacks on foreigners recently". In South Africa, foreigners, especially black foreigners, have come to be perceived as s direct threat to the future economic health of the country (Patel, 2013).

This article sets out to examine the commonly held view that xenophobic attacks are caused by, among others, the perception that foreigners are stealing jobs from South Africans, weak foreign policy, and government's lack of commitment to rooting out xenophobia. According to Steenkamp (2009: 440), xenophobia is a feature of societies under pressure. Undoubtedly, the South African society is under pressure to effectively respond to the sporadic eruptions of xenophobic attacks on foreigners. The first part of this article outlines the path travelled by the South African government on matters of foreign and migration policies, followed by a

\footnotetext{
${ }^{1}$ Department of Public Management \& Administration, North-West University, Vaal Triangle Campus, P.O.
} Box 1174, Vanderbijlpark, 1900, South Africa, E-mail: mpedi.madue@nwu.ac.za 
conceptual and philosophical framework. The second part discusses research design and methodological aspects. The final part presents and discusses the findings, recommendations and conclusion. First, the path travelled by the South African government is discussed hereunder.

\section{The path travelled by the South African government}

Paradoxical though it may sound, South Africa's foreign policy, like that of all other states, is a story essentially of both continuity and change (Landsberg, 2012: 1). In terms of continuity, South Africa's foreign policy is influenced by the international outlook of the African National Congress (ANC), politically and economically. The ruling party, ANC, has embraced the concept of internationalism long before coming into government. It can be argued that the internationalism concept of the ANC can be traced to an article written by Pixley Ka Isaka Seme, published on the $5^{\text {th }}$ April 1906, in which he affirmed himself as “... I am an African”. He was calling on all Africans to rise to the challenges of the new world, using their achievements as a springboard to ascend to the apex of human endeavour in the world. Furthermore, Nqakula (2013: 2) notes that questions relating to international peace were highlighted as part of the ANC's response to the Atlantic Charter, which was endorsed by the Allied Nations on 02 January 1942. On the matter of the destruction of Nazi tyranny, the ANC argued: "Africans are in full agreement with the war aim of destroying Nazi tyranny but, they desire to see all forms of racial domination in all lands, including the Allied countries, completely destroyed. Only in this way, they firmly believe, shall there be established peace which will afford to all peoples and races the means of dwelling in safety within their own boundaries, as well as the assurance that all men in all lands shall live out their lives in freedom from fear, want and oppression".

Fast forward to 1994, a democratic South Africa informed by the ANC policies, developed and adopted policies that would see an increase in the influx of migrants, especially those of African origin. As far as foreign policy is concerned, Nathan (2005: 362) postulates that the 2004 Strategic Plan of the erstwhile Department of Foreign Affairs, now the Department of International Relations and Cooperation, highlights the principles that underpin South Africa's foreign policy, including commitments to the promotion of human rights and democracy, justice and international law in the conduct of relations between nations, international peace and internationally agreed-upon mechanisms for resolving conflict, promoting the interests of Africa in world affairs, and economic development through regional and international cooperation in an interdependent and globalised world.

Crush \& Williams (2003: 3) argue that while over 200 pieces of new legislation were passed, migration legislation was slow to be reconsidered, with the Refugee Act passed in 1998 and the Immigration Act only in 2002. According to Palmery (2003: 3), the Refugee Act of 1998 is generally considered to be a progressive legislation as it allows for any person to apply for asylum and, it states that no person should be denied the right to apply for asylum in South Africa. Despite passing the Refugee Act of 1998, this article argues that the first visible xenophobic attacks in South Africa can be traced to September 1998 when one Mozambican and two Senegalese asylum seekers were killed in a train between Pretoria and Johannesburg, by a mob of unemployed South Africans. Since then, sporadic xenophobic attacks often erupted in townships and informal settlements. The sporadic eruptions of xenophobia in South Africa can be considered to be part of the country's legacy of its racist history. Handmaker \& Parsley (2001: 44) posit that xenophobia “... is also the product of futile, isolationist policy designed to intimidate and control foreigners". In the above discussions, 
concepts such as policy, xenophobia and migration have featured extensively, thus the following section presents a conceptual and philosophical framework that informs this article.

\section{Conceptual and philosophical framework}

A conceptual framework is the basis of the research problem (Wellington et al., 2005: 81). According to Babbie \& Mouton (2005: 111), “... the product of this conceptualisation process is the specification of one or more indicators of what we have in mind, an indication of the presence or absence of the concept we are studying". The concepts that form the framework of this article include policy, ubuntu, Batho Pele, multilateralism and migrant. However, focus of the conceptual framework in this article is on xenophobia.

\section{Policy development and implementation}

South Africa's foreign policy takes into account the ever-evolving global environment in which the country operates in order to respond effectively to domestic imperatives. Effective policy development is essential for the survival and prosperity of any country in the global system (South Africa, 2011: 7). Foreign policy is a multidimensional set of policies, principles, strategies, objectives, and plans that cannot easily be packaged into a neatly described formula (DIRCO, 2009: 13). Foreign policy analysis is typically concerned with the relations of states (Zondi et al., 2014: 8).

\section{Ubuntu (humaneness) and Batho Pele (people first) philosophies}

South Africa's unique approach to global issues has found expression in the concept of Ubuntu. This concept informs the country's particular approach to diplomacy and shapes its vision of a better world for all. This philosophy translates into an approach to international relations that respects all nations, peoples and cultures. It recognises that it is in South Africa's national interest to promote and support the positive development of others. DIRCO (2015: 148) reports that after 1994, inspired by the notion of Ubuntu, South Africa's foreign policy approach was characterised by cooperation, collaboration and the building of partnerships rather than conflict and competition. All departments that represented South Africa internationally were transformed within the first decade of democracy. In the modern world of globalisation, a constant element is and has to be our common humanity. South Africa therefore accords central importance to our immediate African neighbourhood and continent, working with countries of the South to address shared challenges of underdevelopment, promoting global equity and social justice (South Africa, 2011: 4). The philosophies of Ubuntu and Batho Pele can also be understood from a multilateralism perspective.

\section{Multilateralism}

Multilateralism is both a primary goal and strategy for South Africa's foreign policy. The country promotes multilateralism in the international system as the best means of maintaining global order, addressing global problems, mitigating the domination and unilateralism of powerful states, and empowering weaker countries (Nathan, 2005: 365). South Africa has embraced multilateralism as an approach to solve challenges confronting the international community. In this regard, it took up a leading role in various multilateral forums, including SADC, the African Union (AU), Non-aligned Movement (NAM), G77+China, the Commonwealth, and the United Nations, championing the cause of developing countries and, Africa in particular (South Africa, 2011: 7). 


\section{Migrant}

The United Nations defines a migrant as a person living outside his or her country of birth for a year of more. It estimates that the number of such people roughly doubled between 1985 and 2010, from 11 million to 214 million (Martin, 2011: 9). Martin elaborates that “... migration is a process that governments learn to manage; it is not a problem governments ever solve".

\section{Xenophobia}

According to Shisana (2008), xenophobia is a dislike and/or fear of that which is unknown or different from one. It comes from the Greek words (xenos), meaning "stranger," "foreigner" and (Phobos), and meaning "fear." The term is typically used to describe a fear or dislike of foreigners or people significantly different from oneself, usually in the context of visual differentiation. Steenkamp (2009: 439) stresses that the irrationality of the fear when stating that "... xenophobia refers to the irrational fear of the unknown, or especially, as the fear or hatred of those with a different nationality. It relies heavily on the circulation of myths and stereotypes about foreigners". It is from this view that Handmaker \& Parsley (2001: 44) argue that xenophobia is largely based on unfounded myths and stereotypes with foreigners scapegoated for domestic social and economic problems. Thus, in formulating the problem statement, the foreigners are generally accused of stealing jobs and other economic opportunities from South African citizens.

Handmaker \& Parsley (2001), Steinberg (2008), Steenkamp (2009) and Hammerstad (2011) posit that civil servants, particularly those in the Department of Home Affairs, have perpetuated and upheld stereotypes about African migrants and contributed to the intimidation and exploitation of asylum seekers and other migrants. Patel (2013) notes that while xenophobia is a destructive and reactionary force wherever it is found - in France, in Indonesia as in South Africa, the 2006 Xenophobia Survey conducted by the South African Migration Projection found the extent of xenophobic attitudes to be particularly excessive. A critical question to be asked is: what might be the contributing factors of sporadic xenophobic attacks in South Africa? But before attempting to respond to this fundamental question, a research problem, design and methodology need to be stated.

\section{Research problem, design and methodology}

There are legitimate concerns that South Africa's capital, agency, and stature are fast depreciating because of apparent missteps and strategic blunders in the conduct of South Africa's foreign and migration policies, especially on President Zuma's watch. On the one hand, some of South Africa's missteps in foreign policy include the on-going Dalai Lama visa debacles, the misguided and divisive campaign to win the chair of the AU's Commission, and the tragic military misadventure in the Central African Republic (Le Pere, 2013; 2015). On the other hand, teething problems with immigration policies, especially the slow pace with which the Department of Home Affairs processes the applications of asylum seekers, the porous borders, as well as the inhumane way by which detained undocumented migrants are treated, seem to be fuelling myths and misconceptions about foreign nationals

As far as xenophobia is concerned, literature stress that foreigners are typically accused of committing crimes, bringing disease (particularly HIV/Aids), stealing employment and swamping social services (Palmary, 2003; Steinberg, 2008; Steenkamp, 2009; Hammerstad, 2011). Hammerstad (2011: 42) writes that since 1994, South Africa's tough "immigration 
policy was accompanied by intemperate pronouncements on the threats of African immigrants as stealers of jobs, scroungers on welfare, bringers of disease and perpetrators of crime - reflecting widespread and hostile sentiments among the South African populace, particularly in the townships and informal settlements most affected by the influx of undocumented African migrants". It is from this perspective that Steinberg (2008: 1) argues that if the economy is understood as a finite lump, then visible and relative prosperity among foreign nationals is viewed as theft of national resources that ought rightly to belong to South Africans. Thus, Handmaker \& Parsley (2001: 44) hold that xenophobia shows up in many ways starting from derogatory language to extreme levels of violence. If not properly addressed, the factors that fuel xenophobic attacks, particularly the stereotypical myths about foreigners stealing jobs, South Africa will continue to see the sporadic eruptions of attacks on foreigners and thus spoiling the international standing of the country. Therefore, the pertinent questions about sporadic xenophobic attacks on foreigners in South Africa are worth pursuing.

\section{Research questions}

The sporadic eruption of attacks on foreigners of African origin in some South African townships raises pertinent questions about xenophobia. This state of affairs generates invaluable questions that may add new knowledge in the social sciences fields, particularly in the disciplines of Public Administration, Sociology, Development Studies and Law. Therefore, this article is informed by the following research questions:

- How do the twists and turns of South Africa's foreign and immigration policies contribute towards xenophobic attacks?

- Are South African foreign and immigration policies to be blamed for xenophobia?

- Is South Africa really as committed to rooting out xenophobia as it would have us believe?

- Since foreigners are generally accused of stealing jobs from South African citizens, do foreigners really "steal" South African jobs?

Xenophobia is becoming a prominent aspect of life in Africa. Therefore, answers to these research questions might shed some light on the South African government as to how to effectively address the frequent eruptions of xenophobic attacks. A number of other related questions often crop up. For example, le Pere (2015: 51) poses questions which include:

... As an avowedly continental power, can South Africa provide more assertive
leadership in strengthening regional and continental security, especially as far as
peacekeeping and conflict mediation are concerned? By its own example, is it capable of
deepening democracy in the face of manifest reversals in many African countries? And,
given their unsteady and highly politicised genesis as well as huge resource constraints,
can South Africa really rely on the AU and NEPAD to drive the pan-African security,
governance, growth and revival agendas? Is South Africa's faith in the ethical
foundations of multilateralism a sufficient base from which to address the North-South
divide and the growing gap between rich and poor countries? And can South Africa's
global governance reform discourse succeed in a world where the dictates of asymmetric
power and influence still hold strong sway, and where unilateral militarism by the US
is still practiced with impunity?

However, Le Pere (2015) cautions that these matters must be posed against the backdrop of South Africa as a country that is still undergoing a daunting transition, exacerbated and 
scarred by poverty, social unrest, unemployment and inequality. Although questions raised by le Pere (2015) require empirical study, this article attempts to only respond to the four research questions stated earlier on.

\section{Research design and methodology}

This article uses the qualitative research approach as well as the literature review and document analysis techniques. Data was mainly collected from journal articles and research reports. The primary focus of this article is on the myths and misconceptions that South Africans have about foreign nationals, as well as the missteps of South Africa's foreign and migration policies and their effects on xenophobic attacks. In the next section, the findings of this article are presented and discussed.

\section{Findings: Myths or reality?}

In the Southern African Development Community (SADC), South Africa receives the highest number of migrant workers from its neighbours. Nshimbi \& Fioramonti (2013: 1) stress the point that South Africa attracts the largest number of cross-border migrants from Southern Africa. There is evidence that South Africa's current responses to the reality of regional migration in Southern Africa do not provide the most optimal solutions to the phenomenon. Government has the responsibility of effectively managing the influx of migrants, particularly the low-skilled. Martin (2011: 11) posits that migrants are often attractive to local employers because they are willing to work hard in jobs shunned by local workers. Therefore, South Africa constantly develops or amends its policies in an attempt to effectively manage the influx of migrants, as well as strengthen its global reputation. South African policymakers are often hard pressed, facing trenchant critiques for failing to strike a balance between material demands and normative constraints.

The material demands usually entail dealing with divergent constituencies clamouring for domestic expectations of redistribution, on the one hand, and market-led demands, on the other, whilst normative constraints involve having to seek a compromise between cosmopolitanism and pan-Africanism (Van der Westhuizen \& Smith, 2013: 1). Van der Westhuizen \& Smith (2013) elaborate that as a result, multiple contradictions clutter the policymaking domain: a widely pronounced commitment to an "African Agenda" amongst the political elite, set against severe levels of xenophobia amongst the poor, in part because South Africa has had to deal with the largest influx of refugees in the world; increasing trade and economic ties with China, including Chinese sponsorship of South African membership of BRICS, set against massive Chinese imports which have, for example, decimated the local textile industry; and, enunciating a commitment towards 'democratising' international institutions, yet having to tolerate one of the world's last absolute monarchy's in its own backyard. The challenges faced by citizens from Southern African states often lead to an influx of migrants seeking refuge in South Africa. At the same time, in South Africa, myths and misconceptions about migrants and asylum seekers, especially in poor communities, often fuel xenophobic attacks on the foreigners.

There is a disconnection between perception and reality. Myths and misconceptions travel very quickly. If not timeously corrected, such misconceptions will continue to fuel the xenophobic attacks whenever the opportunity arises. A number of surveys have been conducted to determine the extent to which myths and misconceptions fuel xenophobic attacks in South Africa. A study by the Consortium for Refugees and Migrants in South 
Africa found that in 2011, attacks on foreigners continued, with national statistics showing that on average, one person a week was killed, while 100 were seriously injured and over 1 000 were displaced.

As far as the involvement of South Africa in SADC is concerned, Nathan (2005: 366) argues that it has not driven the integration project as many observers expected it to do in the light of its strength in the region. South Africa is a developing country with a relatively small economy, a host of domestic challenges and limited capacity to contribute to external development. Thus, South Africa's foreign and immigration policies are blamed for aggravating xenophobic attacks. The Migrating for Work Research Consortium (MiWORC) has in 2014 released two studies to test the myth that foreigners are stealing jobs from the South Africans. The studies examined the impact that migration might be having on the South African labour market. The findings of their studies suggest that a lot of what has been said is based on hearsay and anecdotal evidence or myths. Evidence from the two studies conducted by MiWORC show that 82\% of the working population aged between 15 and 64 were bona fide South African (non-migrants), with 14\% being domestic migrants who moved between provinces in the past five years. Only $4 \%$ of the working population was found to be migrant workers.

Patel (2013) argues that there is a political vacuum or competition for community leaders allowing scope for the emergence of unofficial, illegitimate and often violent forms of leadership. Such leaders then mobilise residents against foreign nationals in order to strengthen their own powerbase. Therefore, some of the community leaders are fuelling the myths and misconceptions about foreign nationals, thereby contributing towards the eruptions of xenophobic attacks. It is thus necessary to single out some of the major causes of xenophobic attacks.

\section{Causes of xenophobic attacks in South Africa}

The Constitution of the Republic of South Africa, 1996, bestows rights to the citizens and those who live in it, no mention is made whether documented or not. Thus asylum seekers have the right to seek employment, healthcare and education while their application for asylum is still being processed, which could take years to complete. Hammerstad (2011: 2) argues that

... South African immigration system is anti-immigrant in form, but littered with legal practical loopholes. The combination of tough talk and legislation on the one hand, and the inability to stop undocumented immigration in practice, on the other hand, has provided ample breeding ground for discontent and xenophobia in the townships and informal settlements, among police and immigration offices.

South African immigration regulations today put more stringent restrictions on and discourage (especially unskilled) illegal immigration into South Africa, while pursuing a less exclusionary policy towards especially skilled migrants than before (Nshimbi \& Fioramonti, 2013: 3). This policy approach creates pressure on the Department of Home Affairs' handling of asylum applications, which results in inefficiencies and longer turnaround times. The inefficiency and slowness of processing of asylum applications by the Department of Home Affairs renders asylum-seekers more vulnerable, unable to seek work or to claim their right to education (Palmer, 2013: 8). One of the frequently cited explanations of xenophobic attacks is, according to Patel (2013), the discriminatory attitudes learned during apartheid, whose legacy continues. Another explanation of the causes of xenophobic attacks is 
attributable to the criticism of the ANC government's record of service delivery. South African xenophobia has also been explained by the rate of socio-economic inequality in the country. It has been pointed that the greatest scourge of xenophobic violence has been perpetrated in margins of formal society, where foreign nationals compete with the poorest South Africans to eke out a menial living (Patel, 2013).

\section{Recommendations}

Having discussed the findings and some of the causes of the sporadic eruptions of xenophobic attacks, it is important then to highlight some recommendations. South Africa strives to promote its national interest in a complex and fast-changing world. The impact of these complexities and changes must be factored into the nation's attempt to achieve a better life for its people both at home as well as in a regional and continental context. The business of national interest cannot be the purview of the state alone, but it can encourage an enabling environment of dialogue and discourse among all stakeholders to interrogate policies and strategies, and their application in the best interests of the people (South Africa, 2011: 3). South Africa should further be encouraged to establish a SADC-based multi-lateral framework for the management of labour migration and social protection issues (Nshibi \& Fioramonti, 2013: 5). As far as South Africa's foreign and migration policies are concerned, a number of inconsistencies are prevalent. Nathan (2005: 370) stresses that the one major inconsistency with respect to the government's emphasis on Africa and the Africanist approach occurs at the domestic level. There is widespread xenophobia in South Africa, targeted mainly at people from other African countries. In order to counter the toxic levels of xenophobic attacks, Hammerstad (2011: 1) recommends that South Africa's senior political leaders should speak more openly about the political and economic reasons why foreign nationals flee to South Africa. The Skilled Foreign Nationals in South Africa (n.d.) adds that

$$
\begin{aligned}
& \text {... xenophobia must be discussed in the corridors of power and government, in the board } \\
& \text { rooms of big business, in the kraals and assemblies of royal and traditional leaders, in the } \\
& \text { lecture halls of institutions of higher learning and the factory floors of vehicle assembly } \\
& \text { plants. It must be discussed amongst labourers working in fields across the country - } \\
& \text { small and medium business enterprises and operators at community level - churches - } \\
& \text { mosques - and the classrooms where young minds are receptive and shaped - and every } \\
& \text { other place in between. }
\end{aligned}
$$

Traditionally, recommendations are usually drawn from one study. In this article, convention has been challenged, in that, because of the magnitude of the problem of xenophobic attacks in South Africa, it became necessary to also reiterate the recommendations of other related studies. The following recommendations provided by the Institution for Justice and Reconciliation (2015: 2) are also worth noting:

- Education - learners need to learn about other African countries, their people and cultures, geopolitics and histories. The best way to achieve this is to promote a more inclusive and Africentric syllabus. This will assist the broader public and society at large to better understand foreigners in South Africa and why they have immigrated there.

- Immigration policy and integration - South Africa needs clear and concise immigration policies that address who comes into the country, and how, and how those who immigrate are better integrated into society. In particular, there is the need 
to develop integration policies. Currently, integration is left in the hands of local communities.

- Foreign Policy - The foreign policy aims should ultimately be to create opportunities for cultural and economic exchanges between South Africa and the rest of Africa and should lead to a perceived win-win situation on both sides of the border.

- Understanding the problem -There is a need for research on migration and the numbers of foreigners living in South Africa, so that the role of foreign nationals in the employment markets, particularly the low-skill, low-income workforce, is better understood.

- Woundedness - South Africans need to acknowledge that they are a deeply wounded and traumatised people, including their leaders. Wounded leaders cannot lead a wounded nation effectively. South Africa cannot afford not to deal with its past. It is important that government, the private sector and civil society mobilise resources in order to address the trauma, violence and marginalisation at a societal level. Psychosocial support against trauma is necessary for refugees who were affected by conflict and then faced with hardship in South Africa through the need to survive and xenophobia.

This article supports these recommendations as the most practical and viable interventions that could potentially address the challenges of xenophobic attacks against African immigrants in South Africa.

\section{Conclusion}

Since 1994, South Africa adopted a multilateralism approach to pursue its national and global interests. According to Nathan (2005: 36), this is consistent with the country's negotiated settlement and pluralist politics as well as with the emphasis on African state politics on unity and solidarity. As such, South Africa has since then attracted many more migrants, economic and otherwise, and asylum seekers. The increasing number of immigrants from neighbouring countries, coupled with the South African citizens' socio-economic struggles, unemployment and the slow level of service delivery in some instances, often fuel myths and misconceptions about foreigners, especially those of African origin.

In an attempt to address the scourge of xenophobic attacks on foreigners, the South African government often make pronouncements of its commitment to solve this problem. Government acknowledges some shortcomings in its foreign and migration policies. At the same time, xenophobic attacks continue to erupt in South Africa's townships and informal settlement, whenever the citizens become frustrated by the slow pace of service delivery and other related problems. This article has argued that the myths about foreign national persist, and some of the community leaders even use the frustrations of the members of the community to fuel attacks on foreigners, to selfishly strengthen their leadership ambitions. The article is concluded by the words of Patel (2013) who stresses that "... the 2006 Survey confirmed, xenophobia and hostility to (particularly) other Africans is not the preserve of a lunatic fringe, it stems from the xenophobic convictions of the majority of South Africans". The missteps of South Africa's foreign and migration policies are also partially to blame.

\section{References}


Babbie, E. \& Mouton, J. 2005. The Practice of Social Research. Oxford: Oxford University Press.

Centre for Development and Enterprise (CDE), 2011. South Africa's Migration Policies: A Regional Perspective. CDE Workshop No. 8, Centre for Development and Enterprise, Johannesburg.

Department of International Relations and Cooperation (DIRCO), 2009. Vote 3 2009/2010 Annual Report. Pretoria: DIRCO.

Department of International Relations and Cooperation (DIRCO) (South Africa). 2015. Twenty Year Review: South Africa in the Global Arena. Pretoria: DIRCO.

Hammerstad, A. 2011. Linking South Africa's immigration policy and Zimbabwe diplomacy. South African Foreign Policy and African Drivers Programme, Policy Briefing 42, (December): 1-4.

Handmaker, J. \& Parsley, J. 2001. Migration, refugees and racism in South Africa. Refuge, 20(1): 40-51.

Institute for Justice and Reconciliation, 2015. Responses and Recommendations to Counter Xenophobia in South Africa. Institute for Justice and Reconciliation. http://www.ijr.org.za [Accessed: 20 September 2015].

Landsberg, C. 2012. Continuity and change in the foreign policies of the Mbeki and Zuma governments. Africa Insight, 41(4): 1-16.

Le Pere, G. 2013. South African foreign policy in a disorderly world: Will the centre hold? The Thinker, 53: 20-22.

Le Pere, G. 2015. Critical themes in South Africa's foreign policy: an overview. Strategic Review for Southern Africa, 36(2): 31-56.

Martin, P. 2011. Global migration and lessons for South Africa. In Centre for Development and Enterprise, South Africa's Migration Policies: A Regional Perspective, CDE Workshop No. 8, Centre for Development and Enterprise, Johannesburg.

Mouton, J. 2005. Understanding Social Research. Pretoria: Van Schaik.

Nathan, L. 2005. Consistency and inconsistencies in South African foreign policy. International Affairs, 81(2): 361-372.

Nshimbi, C.C. \& Fioramonti, L. 2013. A region without borders? Policy frameworks for regional labour migration towards South Africa. MiWORC Policy Brief, 1: 1-6. African Centre for Migration \& Society, University of the Witwatersrand.

Nqakula, C. 2013. The Foreign Policy of South Africa from 1994 to 2102. Input by High Commissioner of the Republic of South Africa to the Republic of Mozambique, Maputo, 06 March.

Obenzinger, H. 2005. What can Literature Review do for me? How to Research, Write and Survive a Literature Review. http://www.stanford.edu/dept/undergrad/urp/PDFLibrary/writing/LiteratureReveiw [Accessed: 27 July 2015].

Patel, K. 2013. Analysis: the ugly truth behind SA's xenophobic violence. Daily Maverick, 28 May. 
Shisana, H. 2008. We need to address Xenophobia. http://www.xenophobia.com/southafrica/php [Accessed: 02 February 2015].

Skilled Foreign Nationals in South Africa (SFONSA), n.d. Inaugural public lecture on xenophobia. Artspace Theatre, Cape Town, http://www.sfonsa.org [Accessed: 03 October 2015].

South Africa (Republic), 2011. White Paper on South Africa's Foreign Policy. Building a Better World: The Diplomacy of Ubuntu. Final Draft, 13 May. Pretoria: Government Printer.

Steenkamp, C. 2009. Xenophobia in South Africa: what does it say about trust? The Round Table, 98(403): 439-447.

Steinberg, J. 2008. South Africa's xenophobic eruption. Institute for Security Studies, 169 (November): 1-13.

Van der Westhuizen, J. \& Smith, K. 2013. South Africa's role in the world: a public opinion survey. SAFPI Policy Brief, No. 55, Open Society Foundation for South Africa/South African Foreign Policy Initiative.

Webb, W. \& Auriocombe, C.J. 2006. Research design in public administration: critical considerations. Journal of Public Administration, 41(3.1): 588-602.

Wellington, J., Bathmaker, A., Hunt, C., McCulloh, G. \& Sikes, P. 2005. Succeeding with your Doctorate. London: Sage.

Zondi, S., Masters, L., Jumat, W., Reinecke, R. \& Boldt, R. 2014. A Foreign Policy Handbook for Parliament: An Overview of South African Policy in Context. Pretoria: Institute for Global Dialogue, Unisa. 